\title{
Shopping for Health: Herbs and Spices ${ }^{1}$
}

\author{
Jenna A. Norris and Wendy Dahl ${ }^{2}$
}

Herbs and spices have been used for hundreds of years in cooking and medicine (Stephens 2010). They add a wide range of flavors to food and may also provide health benefits. For some people, using herbs and spices in cooking may be a challenge, but it doesn't have to be that way! The information below will get you on track to enjoying zesty, flavorful, healthy cooking.

\section{What's the difference between herbs and spices?}

People often wonder what the difference is between an herb and a spice. It simply depends on the part of the plant that is used. Herbs come from the leaves of plants that do not have woody stems and grow close to the ground in mild climates. Spices are native to warm, tropical climates and are obtained from roots, flowers, fruits, seeds, or bark. Spices tend to have a stronger and more potent flavor than herbs, so they are used in smaller amounts (Spicer 2003). Herbs and spices are commonly referred to as "seasonings" when they are used together.

\section{Do herbs and spices have health benefits?}

Perhaps the greatest health benefit of using herbs and spices is that they serve as flavorful alternatives to salt, fat, and sugar without adding any extra calories to meals. Instead of adding sugar to oatmeal, sweet potatoes, and desserts, try adding spices like cinnamon and allspice. For savory meals, replace salt with spices like black pepper, cumin, and dill

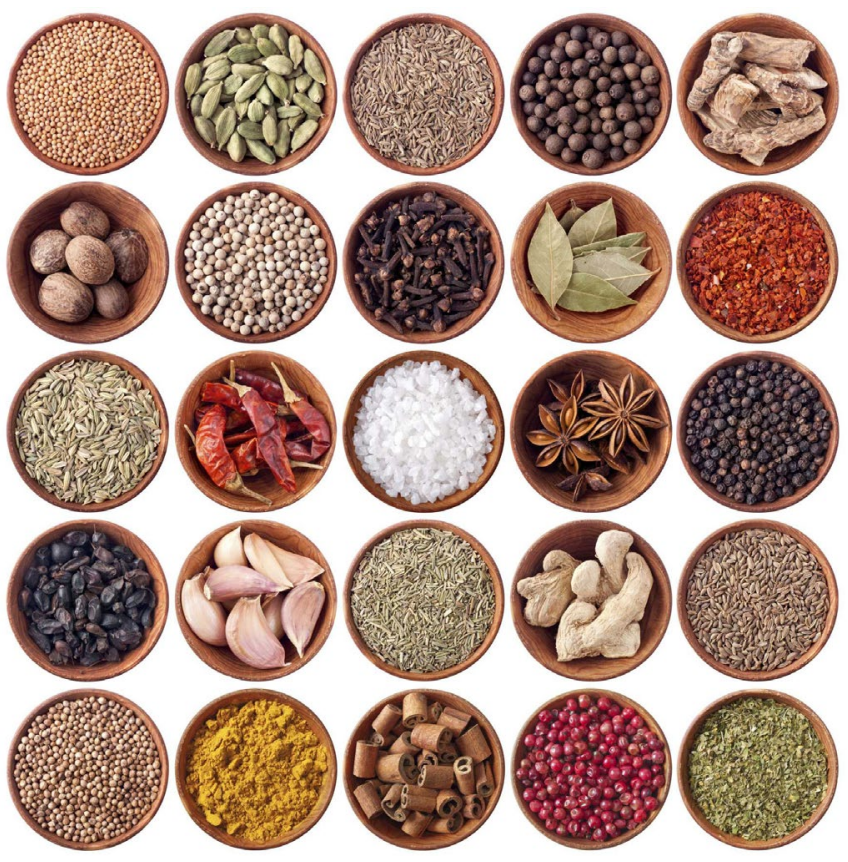

seed. Try flavoring foods with herbs and spices instead of using breading, gravies, and sauces. Seasoning meats with herbs and spices and cooking them on the grill are healthy alternatives to frying and easy, flavorful ways to reduce fat intake. Adopting changes like these can help reduce sodium, fat, and sugar in your diet (Stephens 2010).

\section{Choosing herbs and spices}

Certain seasonings pair better with some foods than with others. Tables 1 and 2 list a few common herbs and spices. There are many more you can try, so be brave and experiment with your own combinations!

1. This document is FSHN13-03, one of a series of the Food Science and Human Nutrition Department, Florida Cooperative Extension Service, Institute of Food and Agricultural Sciences, University of Florida. Original publication date April 2013. Visit the EDIS website at http://edis.ifas.ufl.edu.

2. Jenna A. Norris and Wendy Dahl, assistant professor, Food Science and Human Nutrition Department, Florida Cooperative Extension Service, University of Florida Institute of Food and Agricultural Sciences, Gainesville, FL 32611. 


\section{Should I use fresh or dried herbs?}

The choice is completely up to you. Fresh herbs are not equal to dry in terms of the amounts that should be added to foods. A tablespoon of finely cut, fresh herb is equal to about 1 teaspoon of dried herb or $1 / 4-1 / 2$ teaspoon of ground, dried herb (Stephens 2010). In addition, fresh and dried herbs must be stored differently to ensure freshness. The tips below will help to ensure that seasonings stay fresh long after they are purchased.

\section{Fresh}

When choosing fresh herbs, avoid ones with brown or wilted leaves. Basil, cilantro, dill, oregano, parsley, thyme, and many more should be stored in the refrigerator between $32^{\circ} \mathrm{F}$ and $41^{\circ} \mathrm{F}$. You can expect them to stay fresh for 2-3 weeks, although some of the flavor and aroma will be lost after the first week (Cantwell and Reid 2001). For short-term use (within a week), herbs can be refrigerated in a glass with some water in it and covered with a plastic bag.

\section{Frozen}

To preserve herbs for an extended period of time, you can freeze them. To do this properly, place them on a cookie sheet and then transfer to the freezer. Once the herbs are frozen, package them in airtight containers and store in the freezer. Frozen herbs are limp when thawed, so it is best to use them in cooked dishes (Stephens 2010).

\section{Dried}

Dried herbs and spices never actually spoil, but their flavor and aroma fade over time. They should be stored in a cool, dry place in tight containers and away from heat. When cooking, keep the container away from steaming pots to avoid exposure to moisture (Stephens 2010). Herbs that come in large flakes, such as parsley, basil, and oregano, remain fresh for 1-3 years. Ground spices, such as paprika, cinnamon, and nutmeg, can be kept for 2-3 years. Cinnamon sticks, peppercorns, and any other whole spice can be used for up to 5 years (Dermody 2004).

\section{Cooking with herbs and spices}

Delicate herbs, such as basil or chives, should be added just before serving because their flavor can be lost during the cooking process. Seasonings that are less delicate, such as oregano and thyme, can be added early in the process. Because the flavor of red pepper gets stronger as it is cooked, cayenne pepper should be added in small amounts (about $1 / 8$ teaspoon) to begin with, then increased as needed. Always use small amounts to start with when adding herbs and spices. For 1 pound of meat or 2 cups of a soup or sauce, use $1 / 4$ teaspoon of dried ground herbs and add more if desired (Stephens 2010). When adding herbs and spices to foods that are served cold, it is important to refrigerate the food for a few hours to ensure that the flavors of the seasoning are well absorbed (Johns Hopkins Bayview Medical Center 2001).

\section{Summary}

Using herbs and spices is a great way to reduce sodium, sugar, and fat in your diet while adding bold new flavors. It's a good idea to plan your meals before going to the grocery store so that you know which herbs and spices you will need. Use the advice above to keep seasonings fresh and flavorful. The examples listed above are just a snapshot of possible uses, so be creative! Follow these tips, and you will spice up your cooking in no time.

\section{References}

Cantwell, M., and M. Reid. 2001. "Herbs (Fresh Culinary): Recommendations for Maintaining Postharvest Quality." UC Davis Postharvest Technology. http://postharvest. ucdavis.edu/pfvegetable/Herbs/.

CNN Interactive. 1998. "Herbs and Spices." http://www.cnn. com/HEALTH/indepth.food/herbs/chart.html.

Dermody, C. 2004. “The Shelf Life of Spices." Reader's Digest. http://www.rd.com/food/spice-shelf-life/.

Johns Hopkins Bayview Medical Center. 2001. "Herbs and Spices." http://www.hopkinsbayview.org/nutrition/ patienteducation/healthydirections/herbs.html.

Spicer, F. 2003. "Herbs vs. Spices.” Iowa State University Horticulture \& Home Pest News. IC-489 (21). http://www. ipm.iastate.edu/ipm/hortnews/2003/8-22-2003/herbsnspices.html.

Stephens, J. 2010. "Seasoning with Herbs and Spices." K-State Research and Extension. http://www.ksre.ksu.edu/ bookstore/Item.aspx? catId=390\&pubId=12759. 
Table 1. Common herbs

\begin{tabular}{|c|c|c|c|c|}
\hline Name & Source & Flavor & Best used & Pair with \\
\hline Basil (sweet) & $\begin{array}{l}\text { Leaves and stems of the } \\
\text { basil plant }\end{array}$ & $\begin{array}{l}\text { Pungent, } \\
\text { somewhat sweet }\end{array}$ & Fresh & $\begin{array}{l}\text { Eggs, fish, marinades, meat, salads, sauces, } \\
\text { seafood dishes, stews, tomato dishes, and } \\
\text { vegetables }\end{array}$ \\
\hline Bay leaf & Leaves of the sweet bay tree & Mild & Dried & $\begin{array}{l}\text { Add two or three leaves to gravies, sauces, } \\
\text { soups, and stews (remove leaves before } \\
\text { serving) }\end{array}$ \\
\hline Chive & $\begin{array}{l}\text { Leaves of the chive plant, a } \\
\text { member of the onion family }\end{array}$ & $\begin{array}{l}\text { Sharp, onion/ } \\
\text { garlic flavor }\end{array}$ & $\begin{array}{l}\text { Fresh, or frozen } \\
\text { if fresh is not } \\
\text { available }\end{array}$ & $\begin{array}{l}\text { Chicken, cream cheese, cream sauces, eggs, } \\
\text { fish, lamb, mayonnaise, sour cream, and } \\
\text { vegetable dishes }\end{array}$ \\
\hline Cilantro & $\begin{array}{l}\text { Leaves of the coriander } \\
\text { plant }\end{array}$ & $\begin{array}{l}\text { Spicy, sweet or } \\
\text { hot }\end{array}$ & Fresh & Salsas, guacamole, and salads \\
\hline Dill & $\begin{array}{l}\text { Leaves and seeds of the dill } \\
\text { plant }\end{array}$ & $\begin{array}{l}\text { Mild, somewhat } \\
\text { sour }\end{array}$ & $\begin{array}{l}\text { Leaves are best } \\
\text { fresh; seeds are } \\
\text { used whole }\end{array}$ & $\begin{array}{l}\text { Breads, cream cheese, cottage cheese, } \\
\text { chowders, dips, meat, potato salads, rice } \\
\text { dishes, soups, stews, and vegetables }\end{array}$ \\
\hline Fennel & $\begin{array}{l}\text { Leaves and stems of the } \\
\text { fennel plant }\end{array}$ & $\begin{array}{l}\text { Like anise, but } \\
\text { sweeter and } \\
\text { lighter }\end{array}$ & Raw or cooked & $\begin{array}{l}\text { Fish, Italian sausage, seafood sauces, soup, } \\
\text { spaghetti sauces, stews, and sweet potatoes }\end{array}$ \\
\hline Oregano & Leaves of the oregano plant & Warm and bitter & Fresh or dried & $\begin{array}{l}\text { Eggs, fish, green salads, Italian dishes, meats, } \\
\text { Mexican dishes, mushroom dishes, omelets, } \\
\text { poultry, sauces, soups, spaghetti, spreads, } \\
\text { tomato sauces, and vegetables }\end{array}$ \\
\hline Parsley & Leaves of the parsley plant & Mildly peppery & $\begin{array}{l}\text { Fresh; dried is a } \\
\text { poor substitute }\end{array}$ & $\begin{array}{l}\text { Dips, dressings, garnishes, herb spreads, } \\
\text { omelets, potato dishes, sauces, soups, and } \\
\text { vegetables }\end{array}$ \\
\hline Rosemary & Leaves of the rosemary plant & $\begin{array}{l}\text { Very aromatic, } \\
\text { slightly lemony } \\
\text { and piney }\end{array}$ & Fresh or dried & $\begin{array}{l}\text { Fish dishes, herb breads, marinades, potato } \\
\text { dishes, sauces, soups, and vegetables }\end{array}$ \\
\hline Sage & Leaves of the sage plant & $\begin{array}{l}\text { Musty, slightly } \\
\text { bitter }\end{array}$ & Fresh or dried & $\begin{array}{l}\text { Cheese dishes, chowders, omelets, pork, } \\
\text { poultry, and rice dishes }\end{array}$ \\
\hline Tarragon & $\begin{array}{l}\text { Leaves of the French } \\
\text { tarragon plant }\end{array}$ & Anise-like & Fresh or frozen & $\begin{array}{l}\text { Chicken, fish, salads, salad dressings, sauces, } \\
\text { shellfish, soups, and vegetables }\end{array}$ \\
\hline Thyme & Leaves of the thyme plant & Minty, lemony & Fresh or dried & $\begin{array}{l}\text { Cheese, fish, salad dressings, shellfish, } \\
\text { soups, stews, stuffing, tomato sauces, and } \\
\text { vegetables }\end{array}$ \\
\hline
\end{tabular}


Table 2. Common spices

\begin{tabular}{|c|c|c|c|c|}
\hline Name & Source & Flavor & Best used & Pair with \\
\hline Anise & Seeds of the anise plant & $\begin{array}{l}\text { Sweet, similar to } \\
\text { licorice }\end{array}$ & Dried seeds & $\begin{array}{l}\text { Apple pie, cakes, coleslaw, cookies, cottage } \\
\text { cheese, fruit dishes, salad dressing, and spicy } \\
\text { meat mixtures }\end{array}$ \\
\hline Capers & $\begin{array}{l}\text { Unopened flower buds from } \\
\text { the caper bush }\end{array}$ & Pungent & $\begin{array}{l}\text { Pickled in liquid } \\
\text { brine }\end{array}$ & $\begin{array}{l}\text { Beef gravies, deli sandwiches, eggplant dishes, } \\
\text { salads, sauces, and tomato dishes }\end{array}$ \\
\hline Caraway & Seeds of the caraway plant & Sweet, nutty & Whole & $\begin{array}{l}\text { Baked goods, cabbage, carrots, cheeses, coleslaw, } \\
\text { cucumber salads, green beans, pickles, potatoes, } \\
\text { and sausage }\end{array}$ \\
\hline Cardamom & $\begin{array}{l}\text { Seeds from the cardamom } \\
\text { tree, a member of the ginger } \\
\text { family }\end{array}$ & $\begin{array}{l}\text { Slightly sweet and } \\
\text { also spicy }\end{array}$ & Whole or ground & $\begin{array}{l}\text { Breads, cakes, cookies, curries, custards, punches, } \\
\text { and rice }\end{array}$ \\
\hline Cayenne & $\begin{array}{l}\text { Ground dried fruit or seeds } \\
\text { of the cayenne pepper plant }\end{array}$ & Fiery hot & $\begin{array}{l}\text { Dried and ground, } \\
\text { or fresh and finely } \\
\text { chopped }\end{array}$ & Curries, meats, Mexican dishes, sauces, and stews \\
\hline Celery seed & Seeds of the celery plant & $\begin{array}{l}\text { Strong, pungent } \\
\text { celery flavor }\end{array}$ & Dried whole seed & $\begin{array}{l}\text { Breads, coleslaw, egg salads, potato salads, and } \\
\text { tuna salads }\end{array}$ \\
\hline Cinnamon & $\begin{array}{l}\text { Dried bark of the cinnamon } \\
\text { tree }\end{array}$ & Pungently sweet & $\begin{array}{l}\text { Dried sticks or } \\
\text { ground powder }\end{array}$ & $\begin{array}{l}\text { Breads, cakes, chicken, coffee, cookies, pork, } \\
\text { spiced beverages, sweet potatoes, squash, tea, } \\
\text { yogurt (often paired with allspice, cloves, and } \\
\text { nutmeg) }\end{array}$ \\
\hline Clove & $\begin{array}{l}\text { Dried flower buds of the } \\
\text { clover tree }\end{array}$ & Sweet or bittersweet & Dried and ground & $\begin{array}{l}\text { Baked goods, beets, chili sauces, cookies, curries, } \\
\text { fruit sauces/syrups, gingerbread, squash, and } \\
\text { tomato sauces }\end{array}$ \\
\hline Coriander & Seeds of the coriander plant & Spicy, sweet, or hot & Ground or whole & $\begin{array}{l}\text { Baked goods, beverages, candies, curries, dairy } \\
\text { desserts, meats, and relishes }\end{array}$ \\
\hline Cumin & Seeds of the cumin plant & Peppery & Whole or ground & $\begin{array}{l}\text { Chili powders, curries, meats, stews, tofu, and } \\
\text { vegetable dishes }\end{array}$ \\
\hline Garlic & $\begin{array}{l}\text { Bulbs of the garlic plant, a } \\
\text { member of the onion family }\end{array}$ & $\begin{array}{l}\text { Pungent, onion-like, } \\
\text { mildly hot }\end{array}$ & $\begin{array}{l}\text { Fresh, or granulated } \\
\text { if fresh is not } \\
\text { available }\end{array}$ & $\begin{array}{l}\text { Breads, fish, Italian dishes, meat, soups, stews, and } \\
\text { tomato sauce }\end{array}$ \\
\hline Ginger & Roots of the ginger plant & $\begin{array}{l}\text { Mix of pepper and } \\
\text { sweetness }\end{array}$ & $\begin{array}{l}\text { Dried powder or } \\
\text { freshly grated from } \\
\text { root }\end{array}$ & $\begin{array}{l}\text { Beets, beverages, breads, cakes, cheese dishes, } \\
\text { chutneys, cookies, curries, dipping sauce, } \\
\text { dressings, meat, poultry, soups, stews, and yellow } \\
\text { vegetables }\end{array}$ \\
\hline Mace & $\begin{array}{l}\text { Outer covering of the } \\
\text { nutmeg seed }\end{array}$ & $\begin{array}{l}\text { Similar to nutmeg, } \\
\text { but stronger }\end{array}$ & Dried or ground & Baked goods, pickles, and stews \\
\hline Mustard & Seeds of the mustard plant & Hot and tangy & $\begin{array}{l}\text { Powdered or whole } \\
\text { seeds }\end{array}$ & $\begin{array}{l}\text { Dips, cheese dishes, eggs, fish, pickling spice, } \\
\text { salad dressings, sauces, spreads, tofu, and } \\
\text { vegetables }\end{array}$ \\
\hline Nutmeg & Seeds of the nutmeg tree & Warm, spicy, sweet & Freshly ground & $\begin{array}{l}\text { Applesauce, baked goods, beverages, cheese } \\
\text { dishes, cream dishes, desserts, ground meats, } \\
\text { pies, sauces, soups, stews, and many vegetables }\end{array}$ \\
\hline Paprika & Fruit of a sweet pepper plant & $\begin{array}{l}\text { Sweet to hot, } \\
\text { somewhat bitter }\end{array}$ & Dried and ground & $\begin{array}{l}\text { Eggs, cheese, Hungarian goulash, pasta, potatoes, } \\
\text { and sauces }\end{array}$ \\
\hline Saffron & $\begin{array}{l}\text { Dried stigmas and upper } \\
\text { styles of the saffron crocus } \\
\text { plant }\end{array}$ & Pungent, aromatic & Dried and ground & $\begin{array}{l}\text { Use small amounts crushed in breads, cakes, fish, } \\
\text { poultry, and rice dishes }\end{array}$ \\
\hline Turmeric & $\begin{array}{l}\text { Root of the turmeric plant, } \\
\text { a tropical plant related to } \\
\text { ginger }\end{array}$ & $\begin{array}{l}\text { Pungent, somewhat } \\
\text { bitter }\end{array}$ & Dried or ground & $\begin{array}{l}\text { Curry powders, egg dishes, Indian dishes, rice } \\
\text { dishes, and salad dressings }\end{array}$ \\
\hline
\end{tabular}

